\title{
SATUAN PRAGMATIS PENDUKUNG IMPLIKATUR PERCAKAPAN SISWA KELAS XII IPS 2 DALAM PBM MATA PELAJARAN BAHASA INDONESIA
}

\author{
oleh: \\ Ummi Rahmi ${ }^{1}$, rahmiummi85@gmail.com \\ Mujiyono Wiryotinoyo ${ }^{2}$, mujiyonowiryotinoyo@unja.ac.id \\ Kamarudin $^{3}$, kamarudin_s3@yahoo.co.id \\ Prodi Magister Pendidikan Bahasa dan Sastra Indonesia \\ Fakultas Pascasarjana \\ Universitas Jambi
}

\begin{abstract}
Abstrak-Penelitian ini bertujuan untuk Mendeskripsikan satuan pragmatis (SP) pendukung IP meminta siswa kelas XII IPS. Mendeskripsikan implikasi pragmatis yang mewujudkan IP meminta siswa kelas XII IPS. Metode yang digunakan dalam penelitian ini adalah dengan menggunakan metode analisis deskriptif metode pengumpulan data dengan teknik simak libat cakap yang dibantu dengan catatan lapangan dan perekaman. Data dianalisis dengan mentransripkan hasil percapan dan mengklasifikasikan berdasarkan tujuan penelitian. Hasil penelitian ini, Satuan Pragmatig dalam penelitian ini ada sua belas SP yaitu: menginformasikan fakta, menyatakan kehendak, menyatakan kesenangan, menegaskan, menilai, mengingatkan, memastikan, meyakinkan, mengeluh, bertanya, meminta, dan menyuruh. Alur implikasi yang di temukan ada empat alur, yaitu: alur seba-akibat, alur akibat-sebab, alur normatif dan alur analogis. Rekomendasi yang dapat disampaikan adalah penelitian tentang implikatur percakapan sangat beragam, dan menarik untuk diteliti agar bisa menambah khasanah dalam kebahasaan, terutama bagi peneliti yang mempunyai ketertarikan dalam kajian pragmatik.
\end{abstract}

kata kunci: satuan pragmatis, implikatur percakapan.

\section{A. PENDAHULUAN}

Perkembangan pragmatik di Indonesia yang dimulai tahun 1980-an hingga kini belum mendapat perhatian khusus, penelitian tentang linguistik semakin bertambah setiap waktu, sementara penelitian yang mengarah pada kajian pragmatik masih jauh tertinggal dibandingkan penelitian di bidang linguistik.

Kuatnya pengaruh pandangan struktural dan terbatasnya literatur dan referensi tentang kajian pragmatik membuat pragmatik seperti terpinggirkan jika dibandingkan dengan linguistik. Keterbatasan literatur dan referensi menjadi kendala tersendiri bagi calon peneliti yang akan meneliti kajian pragmatik. Selain itu, pragmatik masih menjadi barang baru dan ilmu yang memerlukan tingkat analisis yang tinggi. Padahal kajian dibidang linguistik kerap menemui kendala dalam mengatasi kebuntuan-kebuntuan yang tak bisa dijangkau dan diselesaikan oleh pandangan struktural. Pandangan struktural masih berkutat dengan unsurunsur bahasa seperti fonologi, morfologi, dan sintaksis, masih berorientasi pada struktur bahasa yang menghasilkan pemahaman yang bersifat teoretis, pragmatik hadir menawarkan solusi atas kendala yang ditemui dalam kajian struktural yang mejembatani bahasa dan fungsinya tanpa melepaskan bahasa dari konteks sosial budayanya. Solusi yang ditawarkan pragmatik diharapkan mampu mencapai tujuan utama pengajaran bahasa yaitu untuk memupuk keterampilan dan kemampuan berkomunikasi.

Kemampuan berkomunikasi merupakan keterampilan yang bisa dipelajari dan dilatih. Sejalan dengan itu, empat kemampuan dasar berbahasa yaitu 
mendengarkan, berbicara, membaca dan menulis menjadi titik fokus pengajaran bahasa Indonesia di sekolah mulai dari tingkat dasar hingga perguruan tinggi.

Kemampuan berkomunikasi tidak hanya dalam bentuk lisan dan kalimat verbal saja, akan tetapi komunikasi dalam kehidupan sehari-hari lebih dari sekedar kalimat verbal saja. Selain kalimat verbal yang berupa bentuk lingual, komunikan juga berkomunikasi dengan cara paralinguistik.

Kalimat verbal dalam bentuk lingual komunikasi yang digunakan terjalin dan dipengaruhi oleh kontek dan situasi ujar yang menuntut penutur dan mitra tutur dan mencapai tujuan yang diinginkan. Kemampuan untuk memahami maksud yang ingin dicapai bersama diperoleh dalam lingkungan dan dipelajari dalam pendidikan formal maupun nonformal.

Akan tetapi kemampuan yang dimiliki belum menjamin terjalinnya komunikasi yang lancar tanpa hambatan. Berbagai kendala komunikasi sering ditemukan dalam kehidupan, dalam berbagai lingkungan didalam kehidupan bermasyarakat. Hambatan-hambatan yang ditemukan dilatarbelakangi oleh berbagai hal diantaranya latar belakang sosial, budaya, keluarga dan tingkat pendidikan serta kemajuan teknologi.

Setiap waktu kemampuan berkomunikasi seseorang akan mengalami perubahan, seuai dengan usia dan faktor eksternal yang mempengaruhi seperti pendidikan. Kemampuan komunikasi siswa usia SD berbeda dengan siswa usia SMP begitupun dengan siswa SMA dan seterusnya.

Selain itu, lingkungan memberikan pengaruh yang besar terhadap perkembangan kemampuan komunikasi seseorang. Pengaruh budaya juga memberi peran terhadap kemampuan berkomunikasi seseorang. Sebagai contoh seseorang yang berasal dari budaya tertentu terbiasa mengungkapkan pikirannya dengan vulgar dan secara langsung, disisi lain seseorang yang berasal dari budaya lain terbiasa mengungkapkan pikirannya dengan menggunakan implikatur.

Implikatur merupakan subkajian dalam pragmatik yang mengkaji makna di balik sebuah tuturan. Implikatur merupakan bagian dari tindak tutur dalam sebuah peristiwa tutur yang memiliki keragaman fungsi dalam berbagai konteks. Implikatur merupakan produk sosiobudaya penutur, sehingga implikatur memiliki kekhasan tersendiri yang menuntut penjelasan fungsional, eksplisit, dan kontekstual.

Penelitian aspek-aspek pragmatik menjadi langkah dalam pengembangan pragmatik itu sendiri. Penelitian-penelitian tentang kajian pragmatik sebelumnya sudah banyak membahas tentang implikatur percakapan, seperti penelitian yang dilakukan oleh Mujiyono Wiryotinoyo dalam Disertasinya yang berjudul Implikatur Percakapan Anak Usia Sekolah Dasar memberikan deskripsi implikatur percakapan oleh anak usia Sekolah Dasar dan telah melahirkan banyak teori tentang kajian pragmatis. Dalam penenlitian ini peneliti tertarik untuk mendeskripsikan dan meneliti implikatur percakapan serta menitikberatkan pada menganalisis alur implikasi dan strategi penguasaan implikatur percakapan remaja siswa SMA. Untuk itu peneliti bermaksud mengadakan penelitian tentang "Satuan Pragmatis yang mendukung Implikatur Percakapan Siswa Kelas XII IPS 2 dalam Proses Belajar Mengajar pada Mata Pelajaran Bahasa Indonesia"

\section{B. KAJIAN TEORI}

1. Implikatur Percakapan

Grice (dalam Wiryotinoyo, 2013:19) mengembangkan teori hubungan antara ekspresi, makna, makna penutur, dan implikasi dari suatu tuturan. Dalam teori itu Grice membedakan adanya tiga macam implikatur: implikatur konvensional, implikatur nonkonvensional (yang dikenal dengan implikatur 
percakapan), dan praanggapan. Selain itu, ia juga membedakan adanya implikatur khusus dan implikatur umum.

Implikatur

konvensional mengandung implikasi yang diperoleh langsung dari makna kata, bukan dari prinsip percakapan. Praanggapan adalah pengetahuan bersama antara penutur dan petutur, oleh karena itu tidak perlu diutarakan. Pengetahuan itu merupakan prasyarat yang memungkinkan suatu pernyataan benar atau tidak benar. kedua implikatur di atas tidak menjadi fokus pemebahasan dalam tesi ini karena peneliti akan memfokuskan pada implikatur nonkonvensional yang dikenal sebagai implikatur percakapan.

Grice (dalam Wiryotinoyo, 2013:21) memperkenalkan kata kerja implicate dan kata benda yang terkait: implicature (cf. implying) dan implicatum (cf. what is implied). Kartomihardjo (dalam Wiryotinoyo, 2013:21) menulis bahwa implikatur yang diutarakan Grice dimaksudkan sebagai sesuatu yang berbeda dengan apa yang sebenarnya diucapkan oleh $\mathrm{n}$.

Menurut Brown dan Yule (1996: 31), istilah implikatur dipakai untuk menerangkan apa yang mungkin diartikan, disarankan, atau dimaksudkan oleh penutur yang berbeda dengan apa yang sebenarnya dikatakan oleh penutur. Pendapat ini bertumpu pada suatu makna yang berbeda dengan makna tuturan secara harfiah.

Selanjutnya Chaer (2010:33) "Implikatur atau implikatur percakapan adalah adanya keterkaitan antara ujaran dari seseorang penutur dan lawan turunya. Namun, keterkaitan itu tidak tampak secara literal, tetapi dapat dipahami secara tersirat."

Sejalan dengan pendapat tersebut, Wijana, (1996:37) menunjukkan bahwa sebuah implikatur merupakan sebuah proposisi yang diimplikasikan melalui ujaran dari sebuah kalimat dalam suatu konteks, sekalipun proposisi itu sendiri bukan suatu bagian dari hal yang dinyatakan sebeumnya. Dengan kata lain Nababan (1987:30) mengatakan "Implikatur percakapan sebagai salah satu aspek kajian pragmatik yang perhatian utamanya adalah mempelajari 'maksud suatu ucapan' sesuai dengan konteksnya. Implikatur percakapan diapakai untuk menerangkan makna implisit dibali 'apa yang diucapkan atau dituliskan' sebagai 'sesuatu yang diimplikasikan'.

Leech menyampingkan apa yang disebutkan oleh Grice Implikatur Konvensional yaitu implikasi pragmatik yang diperoleh langsung dari makna kata, dan bukan dari prinsip-prinsip percakapan. Selain itu, Leech juga menyampingkan fungsi intonasi sebagai petunjuk sikap, dan komunikasi nonverbal melalui gerak isyarat dan paralanguage. Suatu bidang yang sebetulnya gayut dengan pokok bahasan ialah pragmatik referensial yang mengkaji pemberian referensi kepada ungkapan-ungkapan referensial dalam suatu ujaran tertentu, termasuk di dalamnya unsur-unsur indeks atau petunjuk, misalnya, kata ganti persona dan aspek waktu dalam kata kerja (Leech, 1993:17).

Dari beberapa pemapapran para ahli tentang implikatur, dapat ditarik kesimpulan bahwa implikatur percakapan kajian pragmatik yang lebih mengkhususkan pada kajian makna yang implisit dari percakapan yang berupa tuturan antara penutur dan petutur yang berbeda dengan mkna harfiah dari tuturan tersebut.

Untuk mengetahui faedah penting dari konsep IP, Levinson (1983:173) mengemukakan bahwa ada 4 macam faedah konsep implikatur, yaitu sebagai berikut:

1. Dapat memberikan penjelasan makna atau fakta-fakta kebangsaan yang tak terjangkau oleh teori lingustik.

2. Dapat memberikan penjelasan yang tegas tentang perbedaan lahiriah dari yang dimaksud si pemakai bahasa.

3. Dapat memberikan pemberian semantik yang sederhana tentang hubungan 
klausa yang dihubungkan dengan kata penghubung yang sama.

4. Dapat memberikan berbagai fakta yang secara lahiriah kelihatan tidak berkaitan malah berlawanan.

Wiryotinoyo, (2013:19) membedakan tiga macam implikatur, yaitu: (1) implikatur konvensional, nonkonvensional, implikatur praanggapan.selain itu, ia juga membedakan adanya IP khusus dan IP umum.

\section{Satuan Pragmatis}

Dalam komunikasi antara $\mathrm{n}$ dan $\mathrm{t}$, selain menunjukkan fungsi Bentuk Lingual (BL), ilokusi itu sesungguhnya juga mentransaksikan isi komunikasi yang berupa proposisi $(\mathrm{P})$. Dalam menganalisis Implikatur Percakapan (IP), perpaduan antara ilokusi dan $\mathrm{P}$ merupakan suatu satuan analisis tersensiri yang disebut satuan pragmatis (SP). Secara keseluruhan SP juga merupakan isi komunikasi yang disajikan atau diekpresikan dengan BL oleh n. (Wiryotinoyo, 2013:73)

Menurut Wiryotinoyo (2013:73) ada dua belas SP dalam IP anak usia SD yang meliputi SP menginformasikan fakta, menyatakan kehendaka, menyatakan kesenangan, menegaskan, menilai, mengingatkan, memastikan, meyakinkan, mengeluh, bertanya, meminta, dan menyuruh.

2.1 Menginformasikan Fakta

SP menginformasikan fakta adalah suatu SP yang digunakan oleh $n$ untuk menyampaikan informasi atau memberitahukan sesuatu kepada t. SP menginformasikan fakta dalam penyajiannya selalu didukung oleh kalimat berita. Menginformasikan fakta sering sekali dilakukan oleh anak sebagai laporan terhadap orang tuanya tetnagn sesuatu hal yang telah terjadi sehingga banyak SP menginformasikan fakta itu berupa melaporkan (Wiryotinoyo, 2013:73-74).

2.2 Menyatakan Kehendak

SP menyatakan kehendak adalah suatu SP yang digunakan oleh $n$ untuk mengungkapkan kehendaknya, kemauannya, atau niatnya untuk melakukan suatu perbuatan. Perbuatan yang dimaksud belum dilaksanakan, tetapi sudah direncanakan (Wiryotinoyo, 2013:75).

2.3 Menyatakan Kesenangan

SP menyatakan kesenangan adalah suatu SP yang mengungkapkan sesuatu yang disenangi, disukai, ataupun yang diinginkan oleh $\mathrm{n}$. Bentuk menyatakan kesenangan pemunculannya dalam komunikasi disajikan oleh BL yang berupa kalimat berita (Wiryotinoyo, 2013:75).

\subsection{Menegaskan}

SP mengeaskan yaitu suatu SP yang digunakan oleh $\mathrm{n}$ untuk menegaskan sesuatu kepada t. Di dalam komunikasi, SP menegaskan disajikan dengan BL yang berupa kalimat berita (Wiryotinoyo, 2013:76).

\subsection{Menilai}

SP menilai adalah suatu SP yang digunakan oleh $\mathrm{n}$ untuk memberikan penilaian terhadap suatu keadaan, orang, barang, ataupun fakta. Di dalam komunikasi, SP ini disajikan dengan BL yang berupa kalimat berita (Wiryotinoyo, 2013:76).

\subsection{Mengingatkan}

SP meningatkan adalah suatu SP yang digunakan oleh $\mathrm{n}$ untuk mengingatkan sesuatu hal kepada t. Dengan adanya SP ini, $\mathrm{t}$ menjadi sadar, lalu ingat terhadapa sesuatu hal. SP menignatkan dalam penyajiannya didukung oleh $\mathrm{BL}$ yang berupa kalimat berita (Wiryotinoyo, 2013:77).

2.7 Memastikan

SP memastikan adalah suatu SP yang digunakan oleh $\mathrm{n}$ untuk menyatakan kepada $t$ bahwa sesuatu pasti terjadi. SP memastikan dalam penyajiannya didukung dengan BL yang berupa kalimat berita. (Wiryotinoyo, 2013:78).

\subsection{Meyakinkan}

SP menyakinkan adalah suatu SP yang digunakan oleh $\mathrm{n}$ untuk meyakinkan $\mathrm{t}$ melalui pengajuan alasan atau argumentasi dengan harapan $t$ dapat menerima kebenaran argumentasi yang diajukan. SP 
meyakinkan dalam penyajiannya disukung oleh BL yang berupa kalimat berita (Wiryotinoyo, 2013:78).

\subsection{Mengeluh}

SP mengeluh adalah suatu SP yang digunakan oleh $\mathrm{n}$ untuk menyampaikan keluhan kepada t. dengan keluhan itu $n$ berharap agar $t$ mengerti kondisi dirinyanyang memerlukan perhatian atau bahkan bantuan dari orang lain. SP mengeluh dalam penyajiannya didukung oleh kalimat berita (Wiryotinoyo, 2013:79).

\subsection{Bertanya}

SP bertanya adalah suatu SP yang dipakai oleh n untuk menanyakan sesuatu kepada t. Dengan SP itu $n$ dapat meminta informasi atau mengkonfirmasikan sesuatu kepada t. SP bertanya dalam penyajiannya selalu didukung oleh BL yang berupa kalimat tanya (Wiryotinoyo, 2013:79-80).

\subsection{Meminta}

SP meminta atau memohon adalah suatu SP yang digunakan oleh $\mathrm{n}$ untuk meminta sesuatu kepada t. Sesuatu itu misalnya minuman, makanan, mainan, dan buku. Dalam penyajiannya, SP meminta didukung oleh BL yang berupa kalimat berita (Wiryotinoyo, 2013:80).

2.12 Menyuruh

SP menyuruh atau memerintah adalah suatu SP yang digunakan oleh $\mathrm{n}$ untuk menyuruh agar $\mathrm{t}$ atau orang lain melakukan sesuatu untuk kepentingan dirinya ataupun diri orang laian. SP menyuruh dalam penyajiannya selalu disajikan oleh BL yang berupa kalimat perintah (Wiryotinoyo, 2013:81).

Wiryotinoyo (dalam Sari, 2017:22) mengemukakan implikasi pragmatis pada dasaranya merupakan satuan pragmatik yang terselubung yang keberadaannya terimplikasikan didalam satuan pragmatis yang dituturkan secara langsung oleh penutur dalam situasi ujar.

Satuan pragmatis berfungsi agar tuturan $n$ dapat diterima oleh t, karena SP mendukung tesiratnya implikasi pragmatis yang menjadi tujuan terselubung dari $n$ dan mewujudkan implikasi percakapan yang berupa IP menyuruh, meminta, menolak, melarang, mengingatkan, dan lain-lain. Hal ini tergantung pada tujuan yang ingin disampaikan oleh $\mathrm{n}$ kepada $\mathrm{t}$.

\section{METODE PENELITIAN}

Metode penelitian ini merupakan penelitian kualitatif yang menghasilkan data-data deskriptif.Penelititan kualitaif selalu bersifat deskriptif, artinya data yang dianalisis berbentuk deskripsi fenomena.Tidak berupa angka-angka atau koefisien tentang hubungan variabel.Dalam hal ini data yang dihasilkan berupa kata atau gambar bukan angka-angka Aminuddin (dalam Nufriyanti, 2006:44).

Metode deskriptif adalah metode yang berupa prosedur pemecahan masalah yang diselidiki dengan menggambarkan/melukiskan keadaan subjek/objek penelitian (seseorang, lembaga, masyrakat, dan lain-lain) pada saat sekarang berdasarkan fakta-fakta yang tampak atau sebagaimana adanya (Soenjono dan Abdurrahman, 2005:23).

Metode yang digunakan dalam penelitian ini adalah metode deskriptif berdasarkan pada penelitian implikatur yang terdapat dalam percakapan remaja usia SMA. Penelitian ini bertujuan untuk menggambarkan situsi dan fenomena yang terdapat dalam percakapan remaja usia SMA. Pada penelitian ini tidak menggunakan angka-angka melainkan berupa penggambaran terhadap kasus yang terjadi dalam percakapan remaja usia SMA. Impilatur yang dihasilkan remaja siswa SMA. Oleh karena itu dalam penelitian ini menggunakan penelitian kualitatif yang menghasilkan data-data deskriptif.

Sebagaimana yang dikemukakan Melly G Tan (dalam Nufriyanti, 2006:22) penelitian yang bersifat deskriptif bertujuan menggambarkan secara tepat sifat-sifat suatu individu, keadaan, gejala atau kelompok tertentu, atau untuk menentukan frekuensi atau penyebaran suatu gejala dengan gejala lain dalam 
masyarakat. Pelaksanaan metode deskriptif adalah menggambarkan informasi yang faktual dan mendetail tentang implikatur yang diperoleh dan dihasilkan oleh remaja usia SMA.

\section{Kehadiran Peneliti}

Dalam upaya memperoleh data dalam penelitian ini, peneliti berperan penuh sebagai pengumpul data di lapangan, yaitu untuk mengumpulkan data tentang implikatur percakapan remaja usia SMA. Pengumpulan data dilakukan dengan cara mendengarkan dan terlibat langsung dalam pembicaraan, yang secara operasional dibantu dengan perekaman dan pencatatan. Peneliti di sini selain sebagai pengamat juga sebagai lawan bicara yang memberikan stimulus pada remaja usia SMA yang menjadi fokus penelitian.

Dalam penelitian ini, penelitian dilakukan tiga bulan. Penelitian dilakukan dengan cara merekam percakapan remaja yang menjadi sampel penelitian secara alamiah. Proses rekaman di lakukan oleh peneliti sendiri dalam waktu yang tidak beraturan.

\section{Data dan Sumber Data}

Data dalam penelitian ini adalah implikatur yang terdapat dalam percakapan remaja usia SMA. Remaja yang dipilih secara acak jumlah remaja laki-laki dan perempuan seimbang. Remaja usia SMA yang menjadi sampel dalam penelitian ini siswa kelas X dan XII yang memiliki kesempatan yang sama untuk menjadi fokus dalam penelitian ini.

\section{Prosedur Pengumpulan Data}

Teknik pengumpulan data pada penelitian ini adalah teknik Simak Libat Cakap. Menurut Moleong (dalam Mahsun, 2005:221) teknik simak libat cakap atau pengamatan penuh, yang dimaksudkan sebagai upaya penyadapan peristiwa tutur oleh peneliti dengan cara peneliti terlibat langsung dalam peristiwa tersebut.

Teknik pengumpulan data dilakukan dengan langkah-langkah sebagai berikut:
1. Melakukan rekaman terhadap percakapan remaja usia SMA yang mengadung implikatur.

2. Merekam komunikasi remaja usia SMA dalam situasi alamiah di lingkunagan sekolah.

3. Melakukan observasi terhadap pembicaraan remaja usia SMA dengan guru, dan teman sebaya. Kemudian mendengarkan hasil rekaman secara keseluruhan.

Rekaman dilakukan secara alamiah, peneliti mendengarkan dan mengamati serta jika perlu peneliti mengajak remaja usia SMA berbicara dengan topik yang sesuai dengan situasi alamiah pada saat komunikasi terjadi.

\section{Analisis Data}

Data dianalisis dan dideskripsikan dengan langkah-langkah sebagai berikut:

1. Hasil rekaman ditranskripkan ke dalam bentuk tulisan.

2.Mengklasifikasikan data sesuai dengan situasinya.

3. Menganalisis satuan pragmatis pendukung implikatur percakapan remaja usia SMA.

4.Menyimpulkan hasil analisis yang diperoleh.

\section{Pengecekan Keabsahan Data}

Untuk menguji keabsahan data digunakan teknik Triangulasi. Menurut Arikunto (dalam Nufriyanti, 2006:46) Triangulasi adalah upaya untuk mengadakan pengecekan kebenaran data melalui cara lain. Selanjutnya Moeleong (2006:330) menjelaskan bahwa Triangulasi adalah teknik pemeriksaan data yang memanfaatkan suatu yang lain di luar data untuk perbandingan data, misalnya kesiapan remaja usia SMA pada saat berkomunikasi.

\section{HASIL DANPEMBAHASAN}

1 Satuan Pragmatis IP Remaja Usia SMA

\subsubsection{Menginformasikan fakta}

Satuan pragmatis (SP) yang dominan pada IP anak usia SMA adalah SP menginformasikan fakta, yaitu suatu 
SP yang digunakan oleh penutur untuk menyampaikan informasi atau memberitahukan sesuatu kepada pendengar. SP menginformasikan fakta biasanya didukung oleh kalimat berita.Berikut adalah contoh SP menginformasikan fakta.

$$
\begin{array}{ll}
\text { A } & \text { : Woi, sudah bel, Woi. (1) } \\
\text { B : Iyoo } \\
\text { A : Sudah bel, nih.(2) } \\
\text { B : Iyoo, taulah }
\end{array}
$$

Dengan SP pada IP (1) dan (2) penutur menginformasikan bahwa bel tanda masuk sudah berbunyi kepada teman-temannya yang masih berada di kantin belakang kelas.

2.1.2 Menyatakan kehendak.

SP IP ini dapat berupa menyatakan kehendak untuk mengungkapkan kehendaknya, kemauannya, atau niatnya untuk melakukan suatu perbuatan.SP ini juga biasanya disajikan dalam bentuk kalimat berita.Berikut contoh SP menyatakan kehendak.

$$
\begin{array}{ll}
\text { A } & : \text { Jek, geser, Jek. (3) } \\
\text { B : Tunggu. } \\
\text { A : Geser dikit be. (4) }
\end{array}
$$

Dengan SP pada IP (3) dan (4) penutur menyatakan kehendaknya untuk duduk disebelah pendengar, menyatakan kehendaknya untuk duduk disebalah pendengar walaupun tempat ruang untuk duduk hanya sedikit.

\subsubsection{Menyatakan kesenangan.}

SP IP ini yaitu yang mengungkapkan sesuatu yang disenangi, disukai, ataupun yang diinginkan oleh penutur.SP IP ini juga biasanya disajikan dalam bentuk kalimat berita.Berikut contoh SP IP menyatakan kesenangan.

A : Aku suka pakaipena ini, cantik tulisan aku jadinya.(5)

B : Lebai.

A : Seriuslah.

Dengan SP pada IP (5) penutur menyatakan kesenangannya menggunakan pena yang sedang dipakainya untuk menulis kepada pendengar yang duduk disebelahnya.

2.1.4 Menegaskan.

SP IP ini yaitu menegas sesuatu kepada pendengarr.SP IP ini juga biasanya disajikan dalam bentuk kalimat berita.Berikut contoh SP IP menegaskan.

A : Sudah selesai tugas kelompok kita?

B : Aku kelompok Tesa, yee. (6)

Dengan SP pada IP (6) pendengar menegaskan bahwa pendengar adalah anggota kelompok temannya yang bernama Tesa, bukan anggota kelompok penutur.

\subsubsection{Menilai.}

SP IP ini yaitu SP yang digunakan oleh penutur untuk memberikan penilaian terhadap suatu keadaan, orang, barang, ataupun fakta..SP IP ini juga biasanya disajikan dalam bentuk kalimat berita.Berikut contoh SP IP memberikan penilaian.

A : Tas baru aku ni.

B : Banyak nian resletingnya (7)

A : Dak papa, aku suka.

Dengan SP pada IP (7) pendengar memberikan penilaian terhadap tas baru penutur yang dianggapnya kurang bagus karena terlalu banyak resleting.

\subsubsection{Mengingatkan.}

SP IP ini yaitu SP yang digunakan oleh penutur untuk mengingatkan suatu hal, keadaan, janji, ataupun norma yang telah lalu. SP IP ini juga biasanya disajikan dalam bentuk kalimat berita.Berikut contoh SP IP mengingatkan.

A : Sudah tanggal 20 ni Wooii. (8)

B : Bos aku belum gajian, Men.

A : Gek Bu Ummi Marah.(9)

Dengan SP pada IP (8) penutur mengingatkan pada pendengar bahwa sudah tanggal 20, sudah waktunya membayar kas kelas. Pada IP (9) penutur mengingatkan kembali kalau tidak mau bayar kas nanti dimarahi $\mathrm{Bu}$ Ummi.

2.1.7 Memastikan.

SP IP ini yaitu SP yang digunakan oleh 
penutur untuk menyatakan kepada pendengar bahwa sesuatu pasti terjadi.SP IP ini juga biasanya disajikan dalam bentuk kalimat berita.Berikut contoh SP IP memastikan.

A : Jelasin ni? Aku dak paham.

B : Tanya sama Bu Ummi, pasti paham.(10)

A : Ehh..kalau kamu tahu.

Dengan SP pada IP (10) pendengar memastikanjika meminta penjelasan dari Bu Ummi akan menjadi paham dan mengerti.

\subsubsection{Meyakinkan.}

SP IP ini yaitu SP yang digunakan oleh penutur untuk meyakinkan pendengar dengan mengajukan alasan dengan harapan bisa menerima kebenaran alasa yang diajuka.SP IP ini juga biasanya disajikan dalam bentuk kalimat berita.Berikut contoh SP IP meyakinkan.

A : Wooi, kelompok Tesa sudah siap nah.(11)

B : Maknya, jangan cerita terus, dak siap-siap tugas kita ni.

A : Kita juga bisa maju hari ni.(12)

Dengan SP pada IP (11) dan (12) penutur meyakinkan pendengar bahwa anggota kelompok temannya sudah siap, dan kelompoknya juga akan selesai dan siap untuk maju mempresentasikan hasil kerja kelompok di depan kelas.

\subsubsection{Mengeluh.}

SP IP ini yaitu SP yang digunakan oleh penutur untuk menyampaikan keluhan kepada pendengar dengan haran pendengar mengerti kondisi dirinya. SP IP ini juga biasanya disajikan dalam bentuk kalimat berita.Berikut contoh SP IP mengeluh.

A : Tolong woi jelasin ni.

B : Kelompok kami belum siap juga.(13)

A :Sama saja kalau gitu.

Dengan SP pada IP (13) pendengar mengeluh jika tugas kelompoknya belum selesai kepada penutur, yang juga belum selesai mengerjakan tugas kelompoknya.

2.1.10 Bertanya.

SP IP ini yaitu SP yang digunakan oleh penutur untuk menanyakan sesuatu kepada pendengar dengan tujuan memperoleh informasi dari pendengar. SP IP ini disajikan dalam bentuk kalimat tanya. Berikut contoh SP IP bertanya.

A : Jek, sudah selesai belum kelompok kamu ni?(14)

Sudah dalam bentuk Power

Point?(15)

Bisa maju hari ini?(16)

B : Beluuuum, kelompok kamu?

Dengan SP pada IP (14), (15), dan (16) penutur mengajukan pertanyaan kepada pendengar tentang tugas kelompok pendengar.

2.1.11 Meminta.

SP IP ini yaitu SP yang digunakan oleh penutur untuk meminta atau memohon sesuatu kepada pendengar.SP IP ini juga biasanya disajikan dalam bentuk kalimat berita.Berikut contoh SP IP meminta.

A :Casan.(17)

B : Apa? Mau pinjam casan saya?

A : Iya

Dengan SP pada IP (17) penutur meminta kepada pendengar untuk mengambil casan laptop di dekat tempat duduk pendengar.

2.1.12 Menyuruh.

SP IP ini yaitu SP yang digunakan oleh penutur untuk menyuruh atau memerintah agar pendengar melakukan sesuatu utnuk kepentingan dirinya ataupun diri orang lain. SP IP ini biasanya disajikan dalam bentuk kalimat perintah.Berikut contoh SP IP menyuruh.

A : Cabut casan tu!.(18)

B : Yang ini?

A : Bukan, yang sebelahnya.(19)

Dengan SP pada IP (18) dan (19) penutur menyuruh pendengar untuk mencabut casan laptopnya yang tersambung kealiran listrik. 
Tabel Satuan Pragmatis Pendukung IP Siswa Kelas XII IPS 2

\begin{tabular}{|cl|}
\hline 1. Menginformasikan fakta: \\
A & : Woi, sudah bel, Woi. (1) \\
B & : Iyoo \\
A & : Sudah bel, nih.(2) \\
B & : Iyoo, taulah
\end{tabular}

3. Menyatakan kehendak

A: Jek, geser, Jek. (3)

B : Tunggu.

A: Geser dikit be. (4)

4. Menyatakan kesenangan

A: Aku suka pakai pena ini, cantik tulisan aku jadinya.(5)

B : Lebai.

A: Seriuslah.

5. Menegaskan:

A: Sudah selesai tugas kelompok kita?

B : Aku kelompok Tesa, yee. (6)

6. Menilai:
A: Tas baru aku ni.
B : Banyak nian resletingnya (7)
A: Dak papa, aku suka.

7. Mengingatkan:

A: Sudah tanggal 20 ni Wooii. (8)

B : Bos aku belum gajian, Men.

A : Gek Bu Ummi Marah.(9)

8. Memastikan:

A: Jelasin ni? Aku dak paham.

B: Tanya sama Bu Ummi, pasti paham.(10)

A: Ehh..kalau kamu tahu.

9. Meyakinkan:

A: Wooi, kelompok Tesa sudah siap nah.(11)

B : Maknya, jangan cerita terus, dak siap-siap tugas kita ni.

A: Kita juga bisa maju hari ni.(12)
10. Mengeluh:

A: Tolong woi jelasin ni.

B : Kelompok kami belum siap juga.(13)

A :Sama saja kalau gitu.

11. Bertanya:

A: Jek, sudah selesai belum kelompok kamu ni?(14)

Sudah dalam bentuk Power Point?(15)

Bisa maju hari ini?(16)

B : Beluuuum, kelompok kamu?

12. Meminta:

A:Casan.(17)

B : Apa? Mau pinjam casan saya?

A : Iya

13. Menyuruh:

A: Cabut casan tu!.(18)

B : Yang ini?

A: Bukan, yang sebelahnya.(19)

\section{PENUTUP}

\section{Simpulan}

Berdasarkan hasil penelitian dan pembahasan dapat disimpulkan:

Dari 12 jenis SP pada IP siswa kelas XII IPS 2 sudah menguasainya, dan SP itu muncul dari hampir seluruh penutur di dalam kelas tersebut, sehingga peneliti dapat dengan mudah mengidentifikasi ke12 SP tersebut hanya dalam satu kali pertemuan pada proses belajar mengajar dengan metode diskusi kelompok.

\section{Saran}

Pembiasaan penggunaan bahasa Indonesia seharusnya diterapkan pada setiap mata pelajaran, tidak hanya terbatas pada mata pelajaran bahasa Indonesia saja, sehingga siswa tidak merasa canggung dan kaku saat menggunakan bahasa Indonesia dalam kehidupan sehari-hari maupun dalam forum resmi.

\section{DAFTAR RUJUKAN}

Chaer, Abdul. 2010. Kesantunan

Berbahasa. Jakarta: Rineka Cipta.

Leech, G. 1989. Principles of Pragmatics:

Prinsip-prinsip Pragmatik.

Diterjemahkan oleh M.D.D. Oka. 
Bahasa Indonesia Prima, Vol 2. No. 2. 2020 e-ISSN: 2684-6780

1993. Jakarta: UI-PRESS.

Moleong, L. J. 1998. Metodologi Penelitian Kualitatif. Bandung: Raja Karya.

Nasir, Muhammad. 1998. Metode Penelitian. Jakarta: Ghalia Indonesia.
Setyosari, Punaji. 2013. Metode Penelitian Pendidikan dan Penembangan. Jakarta: Prenadamedia Group.

Wiryotinoyo, Mujiyono. 2013. Implikatur Percakapan Anak Usia Sekolah Dasar. Malang: Penerbit Universitas Negeri Malang. 